\title{
A novel mutation in the calcium-sensing receptor gene in an Irish pedigree showing familial hypocalciuric hypercalcemia: a case report
}

\author{
Wael F Elamin ${ }^{1,2^{*}}$, Olivier de Buyl
}

\begin{abstract}
Introduction: Familial hypocalciuric hypercalcemia is a rare autosomal dominant disorder characterized by asymptomatic and non-progressive hypercalcemia due to mutations of the calcium-sensing receptor gene. Disorders of calcium metabolism are very common in the elderly, and they can coexist with familial hypocalciuric hypercalcemia in affected families.

Case presentation: We describe an Irish family with hypercalcemia and hypocalciuria. The proband, an 80-year-old Irish woman, presented with hypercalcemia, relative hypocalciuria, and an elevated parathormone level. She also had chronic kidney disease stage 3 and vitamin D deficiency. Two of her sons were also found to be hypercalcemic and hypocalciuric. DNA sequencing identified a novel missense inactivating mutation in the calcium sensing-receptor gene of the proband and her two hypercalcemic sons.

Conclusion: Familial hypocalciuric hypercalcemia due to a novel mutation in the calcium-sensing receptor gene was diagnosed in the proband and her two sons. Disorders of calcium metabolism can be multifarious in the elderly. We suggest that testing first degree relatives for calcium levels and DNA sequencing may have a role in the assessment of elderly patients with parathormone-related hypercalcemia.
\end{abstract}

\section{Introduction}

Familial hypocalciuric hypercalcemia $(\mathrm{FHH})$ is a rare autosomal dominant disease that runs a benign course. Its prevalence is not clearly established [1]. It is important to differentiate it from the much more common primary hyperparathyroidism (PHPT) to avoid unnecessary and potentially harmful parathyroidectomy [2]. It has been shown to result from heterozygous inactivating mutations in the calcium-sensing receptor (CaSR) gene in the majority of cases [3]. The calcium sensing receptor (CaSR) is a G-protein-coupled receptor of 1078 amino acids (AAs) with a large extracellular domain and the characteristic seven-transmembrane domains [4]. It is expressed in the parathyroid gland, kidneys, bones, and other tissues [5] and plays a key role in the maintenance of constant levels of extracellular ionized calcium. It modulates the function of chief cells of the parathyroid gland, stimulating the synthesis and secretion of PTH as

\footnotetext{
* Correspondence: wael@elamin.net

'Bantry General Hospital, Bantry, Co. Cork, Ireland

Full list of author information is available at the end of the article
}

well as the proliferation of parathyroid cells when the calcium level is low, and inhibiting these functions when the calcium level is high. In the kidneys, the CaSR decreases calcium reabsorption, increases calciuresis, and decreases the concentrating ability of the kidney when sensing hypercalcemia, through its effect on the thick ascending limb of the loop of Henle and on the medullary collecting ducts [6]. Two hundred and twenty-three mutations for the CaSR gene are listed in the CaSR mutation database [7]. Of these, 154 are inactivating (loss-of-function), and most of them cause FHH in heterozygous and neonatal severe hyperparathyroidism (NSHPT) in homozygous patients [3]. Curiously, most of these mutations are confined to a single family, with only a few having been described in more than one family. Inactivating mutations result in decreased sensing of calcium levels, shifting the calcium-PTH curve and the set-point to the right [6]. Elderly patients are frequently affected with disorders of calcium metabolism [8-10]. Here we describe an Irish family in which the proband is an octogenarian with hypercalcemia, hypocalciuria, chronic kidney disease 
(CKD), and low vitamin D level. Because two of her children had hypercalcemia and hypocalciuria as well, we carried out DNA sequencing in the CaSR gene in the patient and three of her children.

\section{Case presentation}

An 80-year-old Irish woman was admitted to our hospital after the onset of a dense right hemiplegia and dysphasia. She had been seen in our hospital previously after an episode of collapse and was diagnosed with hypertension, atrial fibrillation, congestive heart failure, epilepsy, and hypercalcemia. She had a past history of cholecystectomy 33 years earlier. No history of constipation, anorexia, vomiting, bone pains, polyuria or polydypsia, or psychiatric or cognitive disturbance was noted. Her hypercalcemia had been quite severe, ranging between 3.22 and $3.47 \mathrm{mmol} / \mathrm{L}$, with albumin levels of $40 \mathrm{~g} / \mathrm{L}$ on both occasions; the magnesium level was $0.90 \mathrm{mmol} / \mathrm{L}$ (normal, 0.70 to 1.00 ). PTH levels in those instances had been measured between 170 and $235 \mathrm{ng} / \mathrm{L}$ (normal, 10 to $55 \mathrm{ng} / \mathrm{L}$ ). She was taking no medication at the time of sampling. Her urine analysis was negative on three occasions. Arterial blood gases showed no evidence of an acidbase disturbance. Bicarbonate was $25 \mathrm{mmol} / \mathrm{L}$, and chloride was $101 \mathrm{mmol} / \mathrm{L}$. A myeloma screen was negative. Her full blood count was entirely normal. ESR was $12 \mathrm{~mm} / \mathrm{h}$. 25-OH Vitamin D level was shown to be low at $33 \mathrm{nmol} / \mathrm{L}$ (normal, 53 to 150). An X-ray showing the kidney, ureter, and bladder did not show any kidney stones or abnormal calcification.

A bone-density scan was not performed. A parathyroid sestamibi scan was normal. She was offered parathyroidectomy in another hospital; she declined. She remained at home for a period of two years without any obvious symptoms of hypercalcemia. During this admission, she was shown to have had a total left anterior circulation stroke, most probably embolic. She also had an embolism in her leg and eventually died of aspiration pneumonia.

One of her sons (son 1), reported that he was recently found to have hypercalcemia. His own past medical history included gastroesophageal reflux disease (GERD), Barrett esophagus, duodenal polyps with gastric heterotopia, asthma, allergy to shellfish, and hypercholesterolemia.

He informed us that he had seven brothers and no sister. Three of them had died: one at the age of six months of unknown cause; one at the age 26 years of an epileptic seizure; and one at the age of 36 years of pneumonia. Two were living abroad. The remaining two brothers were available for investigations. One of them (son 2), aged 37 years, was affected with hypercholesterolemia, hyperuricemia, and abnormal liver-function tests attributed to excessive alcohol intake. He also had hypercalcemia. His other brother (son 3), aged 50 years, had white-coat hypertension, hypercholesterolemia, and normocalcemia. Their results are presented in Table 1.

The findings of a familial hypercalcemia with relative hypocalciuria were strongly suggestive of a diagnosis of familial hypocalciuric hypercalcemia (FHH). We therefore decided to analyze the calcium-sensing receptor $(C a S R)$ gene. Direct DNA sequencing showed that the proband was heterozygous for a point mutation in the fourth exon of the CaSR gene (GCA $\rightarrow$ GAA), leading to a substitution from alanine to glutamate at position 213 (A213E) (Figure 1). Son 1 and son 2, both with hypercalcemia, were also heterozygous for the same mutation (Figure 2). Son 3, who was normocalcemic, did not carry the mutation (Figure 3 ). The proband, her deceased husband, and their offspring were all from the southwest of Ireland.

\section{Discussion}

This 80-year-old woman was noted to have hypercalcemia, relative hypocalciuria, and an elevated PTH level. Possible explanations for this include the milk-alkali syndrome, the use of lithium or thiazide diuretics, primary hyperparathyroidism (PHPT) associated with vitamin D deficiency with or without low calcium intake [11], FHH, and the combination of FHH with secondary hyperparathyroidism (SHPT) and CKD. The first two possibilities are ruled out by the normal acid/base status and by the negative history of drug intake. The possibility of primary hyperparathyroidism with vitamin D deficiency exists, but the sestamibi scan was negative, and she did not appear to have any of the symptoms of hyperparathyroidism except for the hypertension and the CKD stage 3. The combination of FHH with SHPT could explain the fairly high calcium and PTH observed [12].

Two of the three sons we investigated were hypercalcemic and did carry the same GCA $\rightarrow$ GAA mutation in the CaSR gene as their mother, whereas the normocalcemic son did not, strongly suggesting that the mutation was the cause of the hypercalcemia and the diagnosis of FHH. We did not test the biologic activity of this mutated receptor. This missense mutation leads to the A213E (alanine $\rightarrow$ glutamate) change in the extracellular domain of the protein, in close proximity to one of the calcium-binding sites [13]. Glutamate (acidic side chain) and alanine (nonpolar) belong to different classes of amino acids. This change is therefore likely to affect the conformation of the extracellular domain of the receptor and of its affinity for calcium. Predictive testing by using PolyPhen-2 [14] concluded that the mutation was probably damaging, with a score of 0.982 (sensitivity, 0.66; specificity, 0.94).

The phenotype of FHH in the elderly is bound to be obscured by coexisting common disorders of calcium 
Table 1 Clinical chemistry and mutations

\begin{tabular}{|c|c|c|c|c|c|c|}
\hline $\mathrm{Ca}^{2+}$ & & $\mathbf{P}$ & $\mathrm{F}^{\mathrm{exc}} \mathrm{Ca}^{2+}$ & Creatinine clearance & PTH & CaSR A213E mutation \\
\hline \multicolumn{7}{|l|}{$2.0-2.6$} \\
\hline Normal values and units & $\mathrm{mmol} / \mathrm{L}$ Corrected for albumin & $0.8-1.5 \mathrm{mmol} / \mathrm{L}$ & & $\mathrm{ml} /{ }^{\prime}$ & $10-55 \mathrm{ng} / \mathrm{L}$ & Absent \\
\hline Proband 2001 & 3.35 & 0.67 & & 44 & & \\
\hline Proband 2004 & 3.03 & 0.90 & 0.0035 & 48 & 140 & Present \\
\hline Son 1 & 2.98 & 0.86 & 0.0084 & 80.8 & 20 & Present \\
\hline Son 2 & 2.91 & 0.73 & 0.0044 & 97.8 & 68 & Present \\
\hline Son 3 & 2.40 & 0.93 & 0.0094 & 90.2 & 38 & Absent \\
\hline
\end{tabular}

Serum calcium, phosphate, fraction of excreted calcium (calcium clearance/creatinine clearance ratio), creatinine clearance, PTH, and the presence or absence of the mutation.
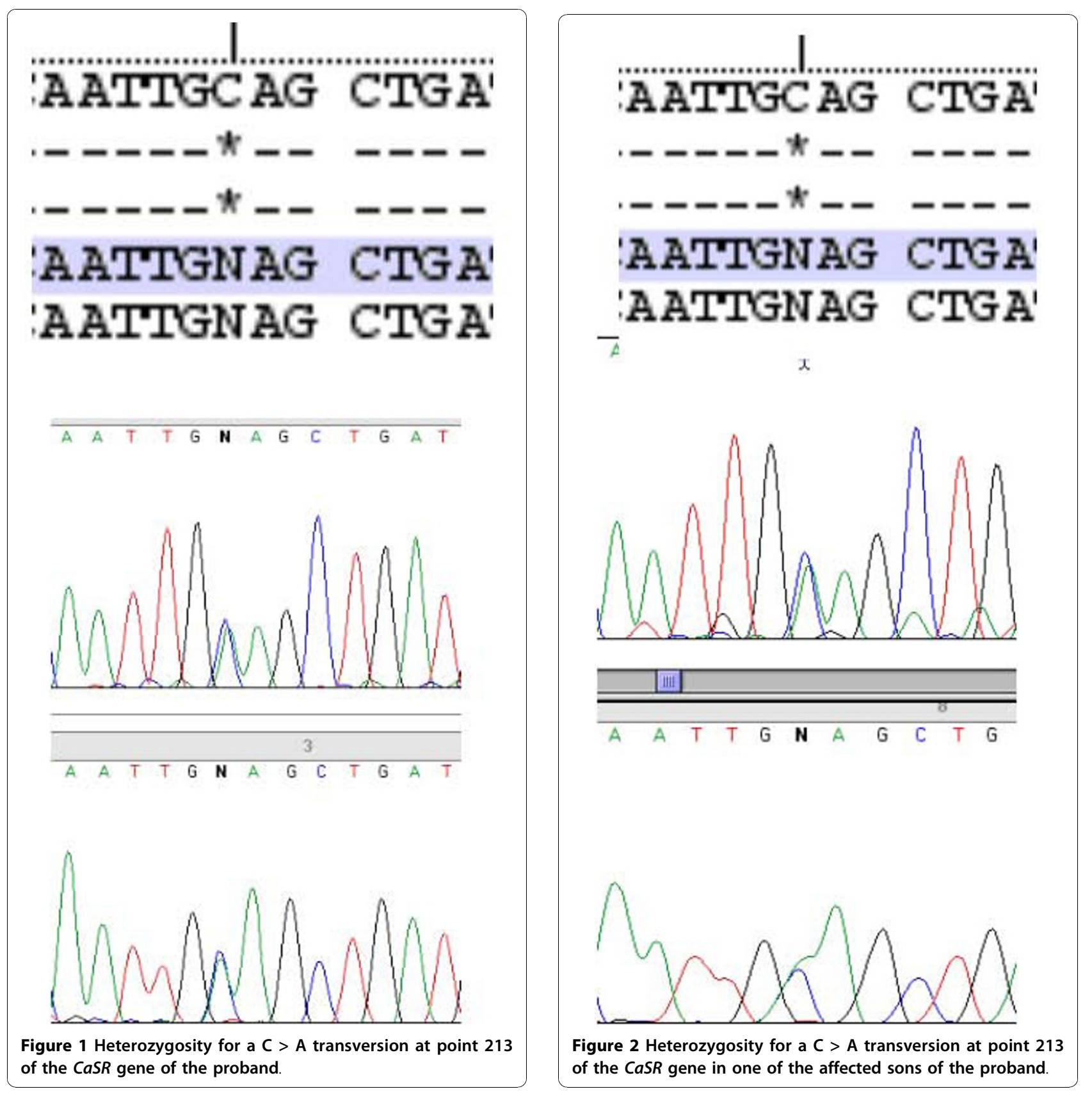


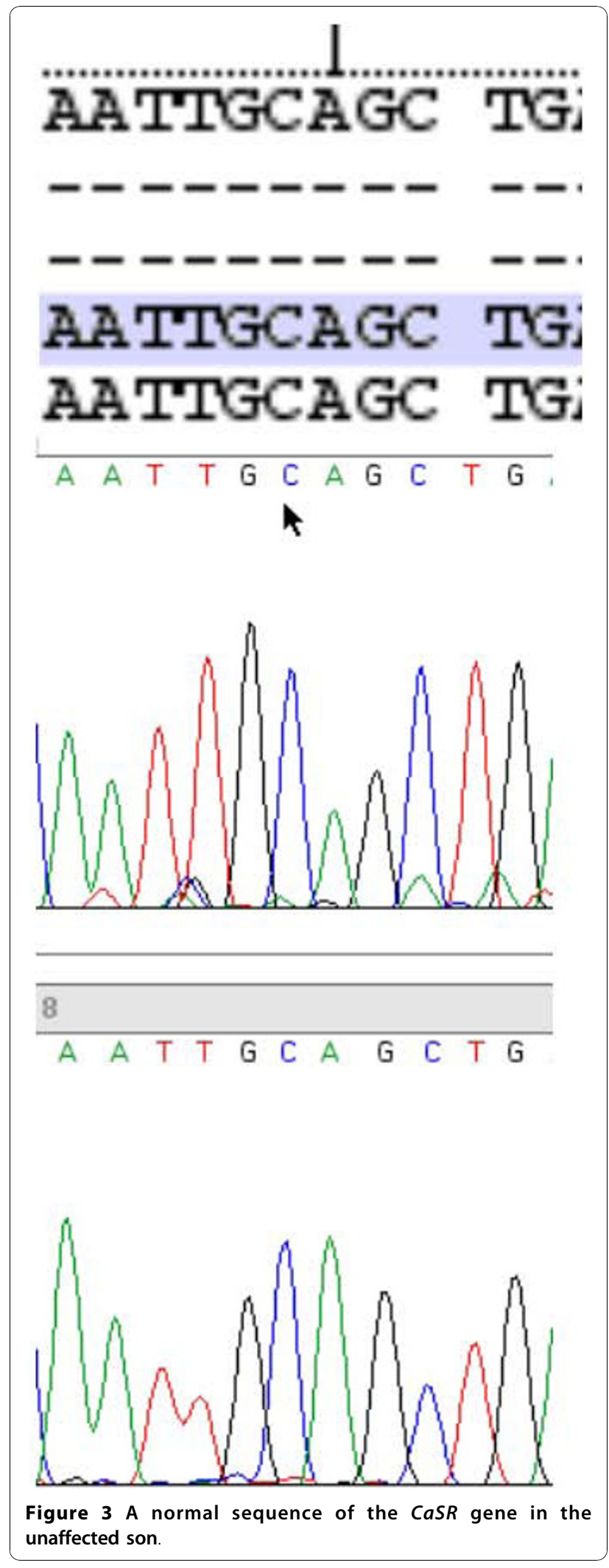

metabolism, and conversely, the manifestations of these common disorders will be different in patients affected by FHH [8-12]. The case of our proband clearly exemplifies this. We suggest that all first-degree relatives of patients with hypercalcemia and inappropriately normal or elevated PTH levels should have a calcium level determined. We also think that DNA sequencing is minimally invasive, is becoming more affordable, can lead to accurate diagnosis, and should therefore be carried out in members of PTH-related families with hypercalcemia and hypercalcemia patients with overlapping fraction of excretion of calcium (0.01 to 0.02). This should also apply to young hypercalcemia patients, any atypical cases in which no first-degree relative is available, and those patients with a typical FHH picture with parents with normocalcemia (to detect de novo mutations).

Moreover, techniques such as denaturing high-performance liquid chromatography (DHPLC) seem to offer a rapid and effective way of screening for mutations in the CaSR gene in these patients [15]. More systematic testing would help prevent unnecessary parathyroidectomies; allow the detection of more cases, give a better idea of the prevalence of FHH and of different mutations in different populations, and help to define the phenotype, such as the set-point, associated with individual mutations.

\section{Conclusion}

The investigation of this Irish family with hypercalcemia led to the diagnosis of $\mathrm{FHH}$ and to the identification of a novel mutation in the CaSR gene. We believe that the molecular diagnosis of $\mathrm{FHH}$ through DNA sequencing or DHPLC of the CaSR gene is clinically useful in the differential diagnosis of hypercalcemia in elderly patients with multiple comorbidities.

\section{Consent}

Written informed consent was obtained from the patient and the members of the family reported for publication of this case report and accompanying images. A copy of the written consent is available for review by the Editorin-Chief of this journal.

\section{Acknowledgements}

We are indebted to Professor A Lienhardt and Dr. Corinne Magdelaine from the Laboratoire de Biochimie et Génétique Moléculaire de l'Hôpital Universitaire Dupuytren de Limoges (France), who carried out the sequencing analysis of the CaSR gene.

\section{Author details}

'Bantry General Hospital, Bantry, Co. Cork, Ireland. ${ }^{2}$ Elrazi College of Medical Sciences and Technology, Khartoum, Sudan. 


\section{Authors' contributions}

WFE analyzed the data and prepared the manuscript. OdB managed the patients, made the diagnosis, and reviewed the manuscript. All authors read and approved the final manuscript.

\section{Competing interests}

The authors declare that they have no competing interests.

Received: 23 October 2009 Accepted: 29 October 2010

Published: 29 October 2010

\section{References}

1. Gunn IR, Gaffney D: Clinical and laboratory features of calcium-sensing receptor disorders: a systematic review. Ann Clin Biochem 2004, 41:441-458.

2. Lyons TJ, Crookes PF, Postlethwaite W, Sheridan B, Brown RC, Atkinson AB: Familial hypocalciuric hypercalcaemia as a differential diagnosis of hyperparathyroidism: studies in a large kindred and a review of surgical experience in the condition. Br J Surg 1986, 225:188-192.

3. Pollak MR, Brown EM, Chou YH, Hebert SC, Marx SJ, Steinmann B, Levi T, Seidman CE, Seidman JG: Mutations in the human $\mathrm{Ca}(2+)$-sensing receptor gene cause familial hypocalciuric hypercalcemia and neonatal severe hyperparathyroidism. Cell 1993, 75:1297-1303.

4. Brown EM, Pollak MR, Seidman CE, Seidman JG, Chou Y-HW, Riccardi D, Hebert SC: Calcium-ion-sensing cell-surface receptors. N Engl J Med 1995, 333:234-240.

5. Egbuna Ol, Brown EM: Hypercalcaemic and hypocalcaemic conditions due to calcium sensing receptor mutations. Best Pract Res Clin Rheumatol 2008, 22:129.

6. Brown EM, Rosen CJ, Mulder JE, eds: Disorders of the calcium-sensing receptor: familial hypocalciuric hypercalcemia and autosomal dominant hypocalcemia. UpToDate 2009, version 17:3.

7. Calcium-Sensing Receptor Database. [http://www.casrdb.mcgill.ca].

8. Holick MF: Vitamin D deficiency. N Engl I Med 2007, 357:266-281.

9. Rosen CJ: Postmenopausal osteoporosis. N Engl J Med 2005, 353:595-603.

10. Abboud H, Henrich WL: Stage IV chronic kidney disease. N Engl J Med 2010, 362:56-65.

11. El-Hajj Fuleihan G, Silverberg SJ, Rosen CJ, Mulder JE, (eds): Diagnosis and differential diagnosis of primary hyperparathyroidism. Up to date 2010 [http://www.uptodate.com], version. 18.1.

12. Zajickova K, Vrbikova J, Canaff L, Pawelek PD, Goltzman D, Hendy GN: Identification and functional characterization of a novel mutation in the calcium-sensing receptor gene in familial hypocalciuric hypercalcaemia: modulation of clinical severity by vitamin D status. J Clin Endocrinol Metab 2007, 92:2616-2623.

13. Huang Y, Zhou Y, Castiblanco A, Yang W, Brown EM, Yang JJ: Multiple $\mathrm{Ca}^{2+}$ binding sites in the extracellular domain of $\mathrm{Ca}^{2+}$-sensing receptor corresponding to cooperative $\mathrm{Ca}^{2+}$ response. Biochemistry 2009, 48:388-398.

14. Adzhubei IA, Schmidt S, Peshkin L, Ramensky VE, Gerasimova A, Bork P, Kondrashov AS, Sunyaev SR: A method and server for predicting damaging missense mutations. Nat Methods 2010, 7:248-249 [http:// genetics.bwh.harvard.edu/pph2/].

15. Cole DEC, Yun FHJ, Wong BYL, Shuen AY, Booth RA, Scillitani A, Pidasheva S, Zhou X, Canaff L, Hendy GN: Calcium-sensing receptor mutations and denaturing high performance liquid chromatography. J Mol Endocrinol 2009, 42:331-339.

doi:10.1186/1752-1947-4-349

Cite this article as: Elamin and de Buyl: A novel mutation in the calcium-sensing receptor gene in an Irish pedigree showing familial hypocalciuric hypercalcemia: a case report. Journal of Medical Case Reports 2010 4:349.

\section{Submit your next manuscript to BioMed Central and take full advantage of:}

- Convenient online submission

- Thorough peer review

- No space constraints or color figure charges

- Immediate publication on acceptance

- Inclusion in PubMed, CAS, Scopus and Google Scholar

- Research which is freely available for redistribution

Submit your manuscript at www.biomedcentral.com/submit
Biomed Central 